\title{
Homofobia no ambiente escolar: uma revisão de paradigmas
}

\author{
Homophobia in the school environment: \\ a review of paradigms
}

\section{Homofobia en el entorno escolar: una revisión de los paradigmas}

\author{
Adilson Cristiano Habowski ${ }^{*}$ \\ Elaine Conte $^{* *}$
}

\begin{abstract}
RESUMO
O presente artigo versa sobre as manifestações homofóbicas influentes no ambiente escolar, objetivando refletir acerca de como os paradigmas cristãos, basilares na construção da cultura ocidental, exercem domínio na moral e no modo de pensar a homossexualidade entre os educadores, obstando o combate à homofobia na prática pedagógica. Esse olhar interpretativo da realidade pretende repensar a homossexualidade na educação, num olhar sensível e aprofundado, para além das aparências. Partindo de uma hermenêutica crítica, almeja contribuir para que os sujeitos homossexuais sejam respeitados na sua integridade. A pesquisa aponta uma interpretação receptiva a um novo olhar histórico-crítico, considerando o contexto da literatura bíblica e as necessidades que o nosso tempo exige. Dessa maneira, pretende-se (re)construir relações humanas em uma expectativa de abertura às diferenças, estabelecendo uma cultura de respeito e compromisso com a alteridade. Para tal fim, o presente texto apresenta a homossexualidade a partir de passagens bíblicas bem pontuais, analisando termos desde o conhecer e a falta de reconhecimento, a questão das abominações e as discussões sobre o desvio do processo natural, até chegar ao problema das relações abusivas entre os seres humanos.
\end{abstract}

Palavras-chave: Homofobia; Bíblia; hermenêutica; Educação.

\begin{abstract}
This article deals with the homophobic influential manifestations in the school environment, in order to reflect on the paradigms, principles in the construction of Western culture, in thinking and moral homosexuality among educators, obstacles to combat homophobia in pedagogical practice. This interpretive look of reality want to rethink homosexuality in education in a sensitive and thorough look beyond appearances. Starting from a critical hermeneutic aims to contribute to that subjects homosexuals are respected in your integrity. The research points to an interpretation open to a new look at historical-critical, considering the context of biblical literature and the needs that our time requires. In this way, we intend to (re) build human relationships in an expectation of openness to differences by establishing a culture
\end{abstract}

* Graduando em Teologia no Centro Universitário Unilasalle, Canoas/RGS. Bolsista FAPERGS - PROBIC. Integrante do grupo de pesquisa NETE/UNILASALLE/CNPq. E-mail: adilsonhabowski@, hotmail.com.

** Professora do Programa de Pós-graduação em Educação do Centro Universitário La Salle - UNILASALLE, Canoas/RGS. Líder do Núcleo de Estudos sobre Tecnologias na Educação (NETE/ UNILASALLE/CNPq).E-mail: elaine.conte@unilasalle.edu.br. 
of respect and commitment to the otherness. To that end, this text presents homosexuality from biblical passages well, analyzing terms since the meet and the lack of recognition, the question of abominations and the discussions about the diversion of natural process, until you get to the problem of abusive relationships between human beings.

Keywords: Homophobia; Bible; hermeneutics; education.

\section{RESUMEN}

Este artículo aborda las manifestaciones homófobas influyentes en el ambiente escolar, con el fin de reflexionar sobre los paradigmas, principios en la construcción de la cultura occidental, en el pensamiento y la homosexualidad moral entre educadores, obstáculos para combatir homofobia en la práctica pedagógica. Este aspecto interpretativo de la realidad quieres repensar homosexualidad en la educación en una mirada sensible y profunda más allá de las apariencias. A partir de una crítica hermenéutica tiene como objetivo contribuir a que los sujetos homosexuales sean respetados en su integridad. La investigación apunta a una interpretación abierta a un nuevo mirar histórico-crítico, teniendo en cuenta el contexto de la literatura bíblica y las necesidades que nuestro tiempo requiere. De esta manera, se pretende (re) construir las relaciones humanas en una expectativa de apertura a las diferencias mediante el establecimiento de una cultura de respeto y compromiso con la alteridad. Para ello, este texto presenta la homosexualidad de pasajes bíblicos, analizando los términos desde el encuentro y la falta de reconocimiento, la pregunta de abominaciones y de las discusiones sobre la desviación natural de proceso, hasta llegar al problema de las relaciones abusivas entre los seres humanos.

Palabras clave: Homofobia; Biblia; hermenéutica; educación.

\section{Considerações iniciais}

Tendo em vista o anseio de construirmos uma sociedade mais justa e humanizada, bem como uma educação mais igualitária, libertadora e emancipadora, livre de qualquer discriminação, escrevemos este trabalho, no sentido de identificar e enfrentar a homofobia nos espaços escolares através de uma reeducação crítica. Nas realidades cotidianas, muitas vezes, a falta de compreensão conceitual alimenta o preconceito no tocante à orientação homossexual. Enquanto profissionais da educação, "teríamos que nos perguntar como nós, que clamamos por justiça, pelo fim de preconceitos e violência, estamos, mesmo sem saber, envolvidos com aquilo contra o que procuramos lutar" (JUNQUEIRA, 2009, p. 13-14). Assim, o ambiente escolar acaba configurando-se como um lugar de discriminação e reprodução de preconceitos, que acabam internalizando sentimentos de culpa desde a infância, inexistindo uma preocupação pedagógica de como devemos agir em situações de homofobia no cotidiano escolar.

Historicamente, nossa cultura ridiculariza pessoas homossexuais, inclusive respaldando consideravelmente algumas atitudes homofóbicas por meio do discurso religioso-cristão, muito em voga nos espaços escolares. Em vista disso, percebemos que os processos educativos precisam ensinar a compreensão dos conteúdos e desenvolver a problematização da realidade, por meio do reconhecimento mútuo, sendo necessário restabelecer, na prática pedagógica, uma atitude hermenêutica de reconciliação com as questões vitais. 
Com esse propósito, entendemos que acolher o método histórico-crítico na interpretação bíblica abre possibilidades para refletirmos sobre as problemáticas sociais, na tentativa de responder à seguinte questão: qual a influência do paradigma religioso-cristão na permanência de um pensar homofóbico no ambiente escolar? Consequentemente, indicamos a possibilidade de mudança de perspectiva no ensino e nas experiências educativas por meio da formação de educadores, nas situações regressivas, onde a consciência é mutilada por meio da autoridade vinculada a modos de agir (moral), de uma forma não-livre, irrefletida e propícia à violência.

Adota-se, como fio condutor para a análise, uma abordagem hermenêutica voltada à compreensão e interpretação de textos que refletem sobre a esfera educacional. Para atingir tal escopo, é essencial identificar a hermenêutica como elemento imprescindível para a superação de tabus que, ainda hoje, se perpetuam na práxis pedagógica. Daí que "o esforço hermenêutico almeja a apropriação de sentido, pressente em cada documento uma voz silenciada que deve ser novamente despertada para a vida" (HABERMAS, 1990 , p. 351). A hermenêutica pressupõe entregar-se ao outro, ao texto, ao diálogo, ao mundo como constante busca de significados mais profundos e sentidos, em meio às contradições existentes. Assim, trazemos para o debate a experiência hermenêutica bíblica e pedagógica com um olhar voltado aos preconceitos instituídos na educação para repensar as visões homofóbicas reproduzidas historicamente.

Tal abordagem aponta para o caráter aberto do diálogo e para um (re)conhecimento que é regulado pela intersubjetividade da prática e por interesses humanos. O diálogo é um processo avesso à alienação provocada por uma leitura fundamentalista (bíblico-cristã), restabelecendo conexões com o outro, com a sociedade que nos faz interpelações. Trata-se de uma retomada do encontro com a alteridade pelo caminho hermenêutico, que permite sair de mecanismos de centralidade e subjetividade para criar possibilidades ético-discursivas descentralizadas, por meio da tomada de posição (auto)crítica e dialógica. Assim, visamos repensar os sentidos contidos em textos bíblicos específicos, reatualizando as leituras frente aos desafios que o nosso tempo apresenta. Trata-se de uma reflexão para sair do imobilismo preconceituoso, reconhecendo as enganações para reconhecer os limites das práticas pedagógicas no entrelaçamento entre racionalidade e realidade social, que expressam a riqueza das identidades pelo diálogo crítico com as diferenças. Esta aporia nos impulsiona para além das formas institucionalizadas de agir e do sofrimento social, sendo enfrentada a questão da homofobia em sua raiz. 


\section{O paradigma religioso cristão frente à homossexualidade}

A incitação de diversos discursos avessos à homossexualidade em ambientes cristãos fundamenta-se em uma leitura tendenciosa da Bíblia. ${ }^{1} \mathrm{O}$ modo como se lê a Bíblia e se interpretam os textos é a chave para a compreensão de determinadas posturas. $\mathrm{Na}$ verdade, os textos antigos, como a Bíblia, devem ser contextualizados, e não servir para mutilar a interpretação, já que podem ter um determinado significado para as contingências atuais distintas da época em que foram escritos. "Para afirmar qual é o ensinamento dado pelo texto bíblico hoje, primeiro é preciso compreendê-lo em sua situação original e, então, transportar seu significado para o presente" (HELMINIAK, 1998, p. 27). Tal entendimento se faz necessário com base no método histórico-crítico. É compreendido como "histórico" porque requer que coloquemos o texto de volta em seu contexto histórico e cultural, para que possamos decidir sobre seu significado. "Esta abordagem é chamada de 'crítica' porque requer um pensamento cuidadoso e uma análise detalhada da Bíblia” (HELMINIAK, 1998, p. 28).

Alguns segmentos cristãos afirmam que a Bíblia deve ser entendida literalmente, sem interpretações. Mas, interpretar requer extrair o sentido real de um texto, em sua constante (re)interpretação. A compreensão é o que dá sentido ao texto. Por isso, não é suficiente simplesmente ler o texto a fim de encontrar, por exemplo, "o que ele diz sobre moralidade sexual. Seu contexto sociohistórico original deve ser esclarecido primeiro e, então, o texto pode ser traduzido, interpretado e inculturado em um contexto contemporâneo" (SALZMAN, 2012, p. 38). A interpretação literal entende o texto conforme o que ele diz, podendo recair em abordagens fundamentalistas. De acordo com o método histórico-crítico, é necessário compreendê-lo em sua gênese e conduzir seu ensinamento para a contemporaneidade. "Assim, se quisermos entender o que Deus quis dizer, o primeiro passo é compreender o que aqueles autores humanos queriam dizer, pois foi precisamente isso que Deus inspirou" (HELMINIAK, 1998, p. 30). Nesse contexto, Wegner (1998, p. 21) destaca algumas das vantagens relacionadas às dimensões históricas e críticas do método, que evita falsas harmonizações em meio à diversidade e pluralidade de posições bíblicas, dentre elas:

Uma análise de textos preocupada com sua gênese histórica e contextual evita a prática prejudicial de extrair sentido de textos de forma seletiva e arbitrária [...] O estudo sério e cuidadoso da intenção histórica original dos textos protege-os contra a fácil manipulação do seu sentido por interesses ou interpretações subjetivas ou, então, determinadas

\footnotetext{
1 A Bíblia manifesta, em algumas passagens, tendências que revelam a superioridade dos brancos em relação aos negros e traços de uma escravidão humana estabelecida por Deus (Gênesis 9,25-27).
} 
por posições ideológicas ou de classe social [...] O estudo da evolução histórica dos textos bíblicos nos torna mais sensíveis para a rica pluralidade que representam os seus diversos estágios de conteúdo [...] A leitura crítica dos textos pode significar um corretivo sadio para o enquadramento unilateral dos mesmos em certos dogmas ou em doutrinas fechadas.

O estudo da homossexualidade é significativamente recente, tendo início no final do século passado. Tendo presente a novidade da investigação, entende-se que não é possível fazer uso da compreensão sexual da conjuntura bíblica para a contemporaneidade, sem a devida crítica. Portanto, quando menciona condutas sexuais entre pessoas do mesmo sexo, a Bíblia o faz de acordo com a compreensão da época, cujos relacionamentos entre pessoas do mesmo sexo eram chamados de homogenitalidade ou relações homogenitais. Mas, o que se discute hoje é a homossexualidade e não mais a mera homogenitalidade ${ }^{2}$. Frente a isso, Daniel A. Helminiak, sacerdote católico, nos auxilia nas análises críticas acerca das passagens bíblicas que geralmente são utilizadas para condenar e oprimir pessoas homossexuais. Todavia, como veremos, não há condenação moral alguma na Bíblia e os homossexuais também devem ser acolhidos. Em nota explicativa, John S. Spong, bispo da diocese de Newark, referindo-se ao livro escrito por Helminiak, salienta que a obra irá "trazer esperança a muitos que se sentem rejeitados por Deus, e seu livro vai ajudar a Igreja a conscientizar-se de que não pode afirmar ser o Corpo de Cristo se deixar de aceitar todos aqueles que seriam bem-vindos pelo Cristo" (HELMINIAK, 1998, p. 12). Apesar dessa e outras produções a respeito, muitas pessoas, como já foi dito, afirmam que a Bíblia condena e exclui qualquer indivíduo que se reconheça homossexual.

Pela carência de estudos na área, muitas pessoas entendem que a Bíblia, verdadeiramente, condena a homossexualidade, acabando por assumir uma postura resignada frente à situação. Diante disso, as únicas alternativas possíveis são desistir da própria homossexualidade, o que é biologicamente impossível, ou desistir de frequentar a Igreja. Para mudar essa situação, nas últimas décadas, diversos biblistas vêm analisando as passagens bíblicas que supostamente abordam o tema da homossexualidade.

O relato de Sodoma, em Gênesis 19,1-11, é uma das passagens bíblicas mais utilizadas quando o assunto é homossexualidade. Além de texto fundamental para a condenação da homossexualidade, desde o século XII

2 Mesmo que algumas traduções bíblicas mencionem a palavra homossexualidade, ela não era empregada no contexto da redação dos textos. O termo homossexualidade foi cunhado em 1869, agregando duas raízes linguísticas: do grego antigo homos (igual) e do latim sexus (sexo). A Bíblia foi escrita há milhares de anos, logo, os escritores não poderiam ter usado uma palavra idealizada na contemporaneidade. 
essa passagem também vinculou a palavra sodomita às pessoas que praticam relações sexuais anais, pondo essas últimas, também, sob a reprovação de Deus. Na referida passagem, é notória a incitação à relação sexual, uma vez que Ló ofereceu suas filhas como objetos sexuais aos homens que estavam em torno de sua casa. Causa-nos estranheza o gesto de Ló, de entregar suas filhas aos sodomitas. Todavia, em sua cultura, o pai era o proprietário das mulheres e, ao oferecer suas filhas aos homens, ninguém mais as desejaria, pois já estavam usadas (HELMINIAK, 1998).

Todavia, na Bíblia Hebraica, a palavra conhecer, que aparece 943 vezes, pode significar, em algumas ocasiões, manter relações sexuais com. O Novo Testamento grego também conserva ocorrências dessa forma de expressão. Por exemplo, quando o anjo lhe diz que será a mãe de Jesus, Maria pergunta: "Como se fará isso, pois não conheço (guinōskô) homem?" (Lc 1,34) (HELMINIAK, 1998, p. 41). Portanto, em ambos os casos mencionados, podemos fazer analogias entre o verbo conhecer e o sentido da sexualidade. $\mathrm{Na}$ passagem de Sodoma, por exemplo, uma das hipóteses é de que os homens queriam apenas conhecer os visitantes e o que ali faziam, afinal, nem Ló era natural da cidade. Por se tratar de um estrangeiro, os habitantes da cidade não teriam visto com bons olhos o acolhimento àqueles estranhos (HELMINIAK, 1998, p. 41). No entanto, a maioria dos estudiosos acredita que esse texto se refere, sim, às relações homossexuais. Porém, se há tal possibilidade, o mais correto é que não se trata de sexo consensual, e sim de abuso sexual.

Está claro que Ló imaginou que os homens da cidade estavam inclinados à violência sexual, uma vez que ele decidiu oferecer suas duas filhas virgens no lugar dos homens. Apesar de que poderíamos achar a oferta de Ló algo repugnante nos dias atuais, nos tempos de Ló, a importância da Lei da Hospitalidade e proteção de hóspedes superava a importância do amor e da proteção à família. Na verdade, podemos concluir, sem receio de enganos, que o comportamento condenável dos sodomitas foi o desrespeito ao seu próprio Código de Hospitalidade em relação aos estrangeiros (DUBE, 2007, p. 9).

Desse modo, “admitindo que a palavra 'conhecer' realmente tenha um significado sexual aqui, o que está em questão é o estupro entre homens, e não simplesmente sexo entre homens" (HELMINIAK, 1998, p. 42). A intenção dos sodomitas revela-se, então, uma grande ofensa, uma vez que forçar um homem a fazer sexo com outro homem era entendido como submetê-lo à humilhação. No entendimento de Helminiak (1998, p. 43), "a ideia era insultar os homens, tratando-os como mulheres. Portanto, fazia parte da prática do sexo anal entre homens a noção de que homens deviam ser 'machos' e de que as mulheres eram inferiores, simples peças que estavam a serviço do homem". 
Portanto, uma das razões da rejeição ao sexo anal entre os homens era que, se o homem agisse como uma mulher, ele se colocava na posição inferior em que as mulheres se encontravam. Diante disso,

A igreja quer mostrar que práticas homossexuais são, como tais, contrárias à vontade de Deus e, assim, contrárias ao bem-estar humano, não simplesmente que os piores excessos da homossexualidade são contrários ao bem-estar humano. Ainda que o ato de estupro homossexual masculino perpetrado por heterossexuais pervertidos seja condenado neste texto, isso está a uma longa distância de uma condenação clara e inequívoca dos atos homossexuais amorosos de pessoas com a mesma orientação homossexual (SALZMAN, 2012, p. 301).

Vemos, então, que era aceitável o homem ser ativo, mas ser receptivo significava desonra e degradação do masculino, no sentido de tirar vantagens, degradar e abusar os outros. Desse modo, "uma prática comum no Oriente Médio, naquela época, em caso de alguém ser derrotado e feito prisioneiro em uma batalha, era o intercurso sexual anal forçado. Como uma maneira de humilhar seus prisioneiros, os vencedores os violentavam" (DUBE, 2007, p. 9).

Diversas passagens bíblicas fazem referências aos relatos da época. Em Ezequiel 16,48-50, muitos veem a homossexualidade a partir da palavra abominação, que aparece no versículo 50. Porém,

nas Escrituras hebraicas, a palavra "abominação" é usada para designar muitas coisas. As abominações em questão aqui são as do "adultério" e "prostituição" de Jerusalém, e estas palavras são utilizadas simbolicamente. Elas não se referem a atos sexuais, mas sim à idolatria, à infidelidade de Israel ao Senhor Deus, e ao sacrifício e assassinato de crianças. Apesar de o versículo 50 mencionar as "coisas abomináveis" e se referir a Sodoma, o versículo 49 diz exatamente quais foram estas coisas abomináveis. Ao afirmar categoricamente qual foi o pecado de Sodoma, o sexo entre homens simplesmente não é mencionado. Fica claro que o capítulo 16 de Ezequiel trata de outras coisas (HELMINIAK, 1998, p. 44).

No Novo Testamento (Mateus 10, 5-16), não há nenhuma alusão à relação sexual, mas, sim, a possíveis situações de rejeição dos mensageiros, ou ainda à falta de hospitalidade. "O paralelo entre o Evangelho e Sodoma é o coração fechado, que rejeita o estrangeiro, a maldade daqueles que não dão as boas-vindas aos arautos divinos" (HELMINIAK, 1998, p. 45). Existem outras alusões a Sodoma na Bíblia, entre elas: Isaías 1,10-17 e 3,9; Sofonias 2,8-11, Jeremias 23,14. As explicações para tais alusões são a opressão, as injustiças, o adultério ${ }^{3}$ e as mentiras. É difícil considerar a narrativa sobre Sodoma como

3 Em relação ao sexo, o pecado referido é o adultério, que ofende o homem ao qual a mulher pertence. Assim, o adultério é a utilização de modo indevido da propriedade que é de outro homem. 
julgamento sobre as relações homossexuais, uma vez que o que estava em discussão era o estupro homossexual e não meramente o ato homossexual. A questão não é o ato sexual com um homem, mas o estupro, a violência, a falta de caridade e, sobretudo, a falta de hospitalidade. É essa atitude que a Bíblia condena. "Portanto, aqueles que oprimem os homossexuais devido ao suposto 'pecado de Sodoma' podem ser, eles próprios, os verdadeiros 'sodomitas', tal como a Bíblia os entende” (HELMINIAK, 1998, p. 46).

A condenação dos atos homossexuais também está contida numa seção do Levítico $(18,22$ e 20,13) chamada O Código de Santidade, cujas leis e punições pretendiam assegurar que Israel conservasse a santidade diante de Deus, distinguindo-se dos seus vizinhos idólatras. Existem hipóteses de que esse Código proibisse o ato sexual entre homens, devido a considerações religiosas, e não sexuais. Todavia, é inevitável perceber que o povo hebreu deve ter experimentado práticas homossexuais durante o período no Egito, a ponto de o sacerdócio expor normas para proibição destes atos de perversão como uma "abominação" relacionada aos cultos idólatras. Em 18, 22, ordena-se: "Não te deitarás com um homem como se deita com uma mulher. É uma abominação". E em 20,13, sentencia: "O homem que se deita com outro homem como se fosse uma mulher, ambos cometeram uma abominação; deverão morrer, e o seu sangue cairá sobre eles".

Naquela época, o povo de Israel estava no meio do deserto e se desviava constantemente dos propósitos de Deus ao se misturar com os costumes de outros povos, dentre os quais as práticas de idolatria, prostituição cultual e sacrifícios sexuais. A partir de uma análise histórica, compreende-se que a prática homossexual no Egito e em Canaã estava articulada diretamente com cultos ligados à questão da fertilidade.

Portanto, a relação sexual entre os homens ofendia os preceitos religiosos e tornaria Israel semelhante aos canaanitas. Naquele período, a homossexualidade, em meio à conjuntura da redação de Levítico, "envolvia atos como deitar com um homem 'como se fosse mulher', que era consequentemente visto pelos hebreus como uma variante não-natural [sic] da heterossexualidade" (MONTALVÃO, 2009, p. 104).

Montalvão (2009, p. 119) expõe uma justificativa interessante para a proibição da penetração anal, que estaria sendo referida em Lv. 18,22 e 20,13: "A proibição está presente porque o homem receptivo na penetração anal não se conforma com a sua classe (homem como oposto à mulher): os limites

\footnotetext{
O texto entende como uma "abominação" um homem deitar-se com outro homem, porém, “abominável' é apenas um sinônimo de 'impuro'. Uma 'abominação' é uma violação das regras de pureza que governavam a sociedade israelita e faziam com que o povo judeu continuasse a ser diferente dos demais povos" (HELMINIAK, 1998, p. 52).
} 
são obstruídos quando um homem assume o papel receptivo".

Dessa forma, as leis de Levítico colocam proibições para que os israelitas não vivessem segundo as mesmas práticas correntes no Egito. A narrativa bíblica diz que os hebreus ficaram aproximadamente 400 anos no Egito, porém, os textos silenciam sobre a conduta de cada indivíduo que compunha o grupo. Tudo indica que a prática sexual era utilizada nos rituais egípcios e canaanitas, incluindo sexo entre pessoas do mesmo gênero. Por exemplo, nesses rituais, famílias inteiras de agricultores, quando desejavam uma colheita próspera, promoviam cultos de fertilidade nos templos dos deuses com os prostitutos cultuais. Desse modo, Levítico não proíbe o relacionamento homossexual, mas condena as formas de adoração a outros deuses, os sacrifícios idólatras, as práticas de prostituição cultual e sagrada, a violência e o abuso sexual, circunstâncias nas quais não existia afeto e reciprocidade.

Conclui-se, então, que as normas somente passaram a existir após as formulações sacerdotais levíticas. "A questão no Levítico era religiosa, e não ética ou moral. Isto equivale a dizer que o sexo, em si, ser certo ou errado nunca foi cogitado. Tratava-se, apenas, da manutenção de uma forte identidade judaica" (HELMINIAK, 1998, p. 51).

A vida no Israel antigo era bem diferente da nossa. Exceto em circunstâncias fora do comum, o sexo em nossa cultura não é parte de rituais religiosos. Atualmente, nenhuma forma de sexo, seja ou não gay, tem a conotação religiosa condenada pelo Levítico. Desta maneira, o código do Levítico é irrelevante para decidir se o sexo gay é certo ou errado. Apesar de o Testamento hebreu certamente condenar a atividade homogenital masculina, as razões desta proibição não exercem influência alguma sobre a discussão atual da homossexualidade (HELMINIAK, 1998, p. 51).

Portanto, o que subjaz a essas assertivas de Levítico é uma dimensão religiosa e não de julgamentos morais, já que não se cogitava que o sexo em si era bom ou mau, mas se o seu uso levava à idolatria e ao afastamento divino. $\mathrm{O}$ texto da Bíblia em que se discute a relação homossexual de forma mais extensa é a Carta aos Romanos, de Paulo, especificamente em 1,18-32. Supõe-se que o versículo 26 aluda à relação de lésbicas, enquanto o versículo 27, aos atos homossexuais. Aliás, é o único lugar na Bíblia em que se menciona o sexo entre mulheres. É desse texto que se tira a conclusão de que a relação homossexual não é natural e acarretaria punições. No texto de Romanos 1,23-32, surgem as seguintes colocações:

Mudaram a majestade de Deus incorruptível em representações de figura de homem corruptível, de aves, quadrúpedes e répteis. Por isso, Deus os entregou aos desejos (akalharsiâ) de seus corações, à imundície, de modo que desonram entre si os próprios 
corpos. Trocaram a verdade de Deus pela mentira, e adoraram e serviram à criatura em vez do Criador, que é bendito pelos séculos. Amém. Por isso, Deus os entregou a paixões (atimias) vergonhosas: as suas mulheres mudaram as relações naturais (physiken) em relações contra a natureza (para physin). Do mesmo modo também os homens, deixando o uso natural (physiken) da mulher, arderam em desejos uns para com os outros, cometendo homens com homens a torpeza (aschemosynè), e recebendo em seus corpos a paga devida ao seu desvario. Como não se preocupassem em adquirir o conhecimento de Deus, Deus entregou-os aos sentimentos depravados, e daí, o seu procedimento indigno. São repletos (pepleromenous) de toda espécie de malícia (adikia), perversidade, cobiça, maldade; cheios de inveja, homicídio, contenda, engano, malignidade. São difamadores, caluniadores, inimigos de Deus, insolentes, soberbos, altivos, inventores de maldades, rebeldes contra os pais. São insensatos, desleais, sem coração, sem misericórdia. Apesar de conhecerem o justo decreto de Deus, que considera dignos de morte aqueles que fazem tais coisas, não somente as praticam como também aplaudem os que as cometem (HELMINIAK, 1998, p. 68).

No trecho 1,26-27, o fato de Paulo dirigir-se primeiramente às mulheres e depois aos homens revela-se proposital, a fim de dar maior ênfase em relação aos homens. Paulo mostra a intenção de estar em conformidade com o Criador, com a doutrina bíblica da criação. Nessa ótica, faz uso dos termos natural e contra a natureza. De acordo com Bortolini (1997, p. 31),

A carta destaca algumas dessas relações pervertidas. A primeira é o homossexualismo feminino e masculino (1,26b-27). De modo geral, no mundo greco-romano daquele tempo, a prática homossexual entre pessoas heterossexuais era estimulada e inclusive vista como perfeição. Paulo certamente não tinha o conhecimento que hoje se tem a respeito de pessoas que já nascem com orientação homossexual. Ele detecta perversão entre heterossexuais que se dedicam a práticas homossexuais.

A condenação da Carta aos Romanos referia-se à experimentação de formas sexuais contra a natureza, pelo simples desejo ou busca de prazer, sem a orientação sexual correspondente. Portanto, é notório que Paulo condena o relacionamento heterossexual agindo contra a natureza ${ }^{5}$ humana. Ao estudar os termos gregos, percebemos que os homens e mulheres estavam envolvidos em práticas sexuais que não eram comuns. Isso se comprova quando outras passagens são levadas em consideração, por exemplo, Romanos 11,24, em que

\footnotetext{
Physis é a palavra grega que significa "natureza". Ela é a raiz da palavra "física", que significa o estudo da natureza. A forma adjetivada desta mesma palavra, physikos, tem seu equivalente em português no termo "fisico", significando aquilo que é do corpo. Mesmo em português, palavras com a mesma raiz têm sentidos diferentes [...] temos bem claro que Paulo não usou a palavra 'natureza' com o mesmo sentido abstrato e genérico que empregamos ao citar "a Natureza e as leis da Natureza". O uso que Paulo fez do termo foi bem mais concreto. Para Paulo, a "natureza" de alguma coisa era sua característica ou tipo particular (HELMINIAK, 1998, p. 69).
} 
Paulo faz uso dessas mesmas palavras para referir-se a Deus: "Com efeito, se tu foste cortado da oliveira silvestre por natureza e, contra a natureza foste [sic] enxertado na oliveira cultivada, com maior razão os ramos naturais serão enxertados na oliveira a que pertencem". Em outras palavras, Deus fez algo que não poderia ser considerado natural, comportou-se de modo incomum.

\begin{abstract}
Não há, nestas palavras, qualquer acepção indicando que as práticas estavam erradas ou eram contrárias a Deus ou iam de encontro à ordem divina da criação, nem que estavam em conflito com a natureza universal das coisas. Segundo o sentido em que Paulo as emprega, estas palavras dizem apenas que aquelas práticas eram diferentes daquilo que normalmente seria o esperado. Ao invés de "não naturais", as palavras para physin em Romanos seriam traduzidas de maneira mais precisa como "não usuais", "peculiares", “fora do comum” ou 'não características' (HELMINIAK, 1998, p. 71).
\end{abstract}

Hoje, há um grande debate dentro das pesquisas bíblicas, que compreendem para physin com o significado de contrário à natureza. A filosofia afirmava que a finalidade do sexo era a procriação, de modo que fazer sexo sem finalidade procriadora violaria a natureza deste ato. Dois outros textos do Novo Testamento fazem menção a relações homossexuais. Em 1 Coríntios 6,9-10, de acordo Helminiak (1998, p. 96), a tradução é a seguinte: "Não vos enganeis: nem os impuros, nem os idólatras, nem os adúlteros, nem os efeminados (oute malakoi oute arsenokoitai), nem os devassos, nem os ladrões, nem os avarentos, nem os bêbados, nem os difamadores, nem os assaltantes hão de possuir o reino de Deus". Por sua vez, o texto de 1 Timóteo 1,9-10, segundo Helminiak (1998, p. 96), diz: “a lei não foi feita para o justo, mas para os transgressores e os rebeldes, para os ímpios e os pecadores, para os irreligiosos e os profanadores, para os que ultrajam pai e mãe, os homicidas, os impudicos, os infames (arsenokoitai), os traficantes de homens, os mentirosos, os perjuros, e tudo o que se opõe à sã doutrina".

Do ponto de vista social, Torres (2012, p. 27) faz esta observação: "A cidade de Corinto, destinatária da epístola de Paulo, e Éfeso, onde Timóteo vivia [sic], eram reconhecidos centros das religiões de fertilidade. Em Corinto, adorava-se Afrodite (ou Vênus); em Éfeso, Artemisa (ou Diana)". Dentro da cidade de Corinto havia um templo à deusa Afrodite, onde ficavam sacerdotisas que, aos finais de tarde, iam à cidade para se prostituírem, cultuando o sexo. A prostituição também era feita por homens, que deixavam os cabelos longos, símbolo da prática, e tinham aspectos afeminados. Aliás, “os sacerdotes de Artemisa eram castrados e vestidos com roupas femininas [...] Duzentos anos depois de Paulo, Eusébio de Cesareia ainda faz referência à prostituição de mulheres e homens efeminados no culto a Afrodite" (TORRES, 2012, p. 27). 
Diante das diversas interpretações bíblicas, podemos dizer que o termo “malakos simplesmente não se refere à atividade homossexual; I Coríntios 6,9 utiliza malakos para fazer uma condenação generalizada da lassidão moral e do comportamento libertino, da luxúria e da lascívia" (HELMINIAK, 1998, p. 99). De acordo com Torres (2012, p. 28), na literatura paulina, "quatro contextos principais têm sido propostos para o significado de arsenokoitai: exploração sexual (cafetinagem/exploração sexual); pederastia; sexo não consensual entre homens (estupro); ou sexo consensual entre homens (homossexualismo)". Os textos de Paulo condenam especificamente a luxúria, a lascívia e os atos homogenitais masculinos irresponsáveis, "por essas razões, pode-se dizer que a tradução de arsenokoitai por 'homossexuais' não é incompatível com a evidência" (TORRES, 2012, p. 45-46). Assim sendo, alegar que esses textos fazem condenações à homossexualidade ou às relações homossexuais é partir de uma premissa que não leva em consideração a confrontação dialética entre concepções e a compreensão sociológica.

\section{Repercussões do pensamento religioso-cristão no ambiente escolar e a formação de educadores}

Certamente, não são poucos os relatos de preconceitos, violências verbais ou físicas ocorridas contra pessoas homossexuais em instituições de ensino. No que tange à orientação da pessoa homossexual, em inúmeras ocasiões, algumas igrejas cristãs acabam endossando tais atitudes, justificando-as pelos princípios bíblicos, já que tomam por base uma leitura literal da Bíblia. Por isso, a pedagogia e a religião cristã devem encontrar pontos de diálogo através de aprofundamentos teóricos para oportunizar reflexões sobre a temática, que conduzam a mudanças, tendo em vista uma educação humanizadora. A educação surge como um grande potencial, visto que:

A adequada discussão dessas questões deve ser feita sempre levando em conta que a escola é um espaço público, e necessariamente laico. Desta forma, aquilo que as religiões pensam e dizem acerca da sexualidade humana não deve virar regra dentro da escola. As regras da escola são as regras do espaço público, regras democráticas de convívio, valorização e respeito da diferença. Escola não é igreja e professor não é sacerdote ou pastor. Quem quiser participar de um espaço onde homossexuais não entrem pode

\footnotetext{
A palavra malakoi (malakos significa macios, moles), em 1 Coríntios 6,9, foi traduzida pela Bíblia de Jerusalém como depravados. Em 1 Timóteo 1,10, a palavra arsenokoitai é vertida por pederastas, ou seja, adultos que fazem sexo com crianças ou passam a deitar-se com, ter relações sexuais com. $\mathrm{O}$ pecado não está no fato de relacionar-se com homem ou ter características de mulher, mas porque o intuito era de prostituir-se. Helminiak (1998, p. 96) esclarece que "até a Reforma no século XVI e no catolicismo até o século XX, pensava-se que a palavra malakoi significasse 'masturbadores'. Parece que as traduções da Bíblia vêm se modificando conforme os preconceitos”.
} 
criar o seu espaço para isto, mas a escola não é local onde isso possa ser feito; ela é um espaço público, como o são ruas, praças, hospitais públicos, postos de saúde, assembleias legislativas, apenas com regras diferentes de acesso e convivência, e propósitos e objetivos claramente diferentes de outros espaços públicos (SEFFNER, 2009, p. 135).

A apresentação de alguns textos bíblicos a respeito da homossexualidade, a partir de um viés histórico-crítico, vem justamente demonstrar a necessidade de revisão das expressões e posicionamentos, entrando em consonância com a comunidade de interpretação em que vivemos. Só assim será possível perceber as distorções das leituras obtidas durante a trajetória da humanidade e, por muitas vezes, carregadas pelo imaginário social na formação de subjetividades. Desse modo, não se pode negar a influência da religião cristã na formação dos repúdios, no que se refere à homossexualidade, de modo especial em relação aos decretos políticos que institucionalizam as formas de educação no Brasil.

No Congresso Nacional Brasileiro, representantes da política ligados à igreja católica e às igrejas evangélicas têm se mobilizado contra a aprovação de direitos civis das minorias sexuais como a criminalização da homofobia, a união civil de casais homossexuais e o direito de adoção de crianças por parte das famílias homoparentais. Associações entre o comportamento homossexual, a promiscuidade e a causa de catástrofes naturais associadas a mudanças climáticas e o aparecimento de novas doenças também são comuns em programas televisivos comandados por religiosos durante as madrugadas (DINIS, 2011, p. 46).

Se o legislativo se torna dependente das questões religiosas, ampliando tabus históricos, isto se revela também na educação, pela dificuldade em tratar o conteúdo da sexualidade com as crianças, em cartilhas didáticas ${ }^{7}$, fazendo com que a população continue a reproduzir preconceitos. Parlamentares provindos das igrejas católica e evangélicas surgem representando ideologias que legitimam discursos homofóbicos, portanto, discriminatórios, contra sujeitos homossexuais e suas organizações familiares. Pior ainda é que as políticas públicas educacionais acabam inviabilizando o pensar sobre o tema na formação de professores e na sala de aula, bem como privilegiando discursos irrefletidos do mundo da vida e perversos para o reconhecimento das diferenças e para o avanço da democracia.

As questões sobre educação sexual aprovadas pelo Ministério da Educação ainda podem trazer efeitos contrários ao planejado, uma vez que os professores e as crianças podem não ter formação e maturidade para debater este assunto, incitando as crianças a praticar relações sexuais precoces ou, ainda, podem servir como estímulo prematuro às relações sexuais, podendo desenvolver doenças ou até gravidez indesejada. 
A questão é saber se a religião, na atualidade, contribui para a perpetuação de distorções sobre a orientação homossexual, tornando-se, assim, geradora de instrumentos normativos nos espaços escolares. Tudo indica que, no Brasil, a religião cristã seja o credo quase que hegemônico. De fato, algumas perícopes bíblicas específicas têm se tornado como que verdades absolutas para os cidadãos brasileiros. Isso talvez se dê pela ignorância da parte de alguns pastores ou sacerdotes das igrejas cristãs, pela busca de interesses pessoais, ou ainda pelo medo que os clérigos têm de entrarem em desacordo com o magistério da igreja.

No artigo A igreja e a questão homossexual no Brasil, o pesquisador Luiz Mott, analisando o conteúdo homofóbico expresso no discurso das religiões cristãs brasileiras, observa que muitos de seus adeptos "pensam e agem em relação aos homossexuais como se ainda vivêssemos sob o chicote e a fogueira da Santa Inquisição" (DINIS, 2011, p. 46).

Torna-se importante destacar, ainda, que, na história de nossas sociedades, entre outras de suas expressões, o preconceito tomou a forma da opinião religiosa que, misturando às crenças uma visão também naturalista da sexualidade, se traduz na versão segundo a qual a heterossexualidade é a forma sexual herdada da natureza pelo homem e sendo a natureza uma criação de Deus - tudo que esta forma contraria não apenas contraria a natureza, contraria igualmente a vontade divina. Explica-se, assim, porque a homossexualidade é banida nas religiões para o campo dos "pecados", dos "atos impuros", das "anomalias", dos "vícios", das "depravações" ou, na erudição de seus chefes, representa "quando menos, desordem da identidade de gênero" - os termos são de Joseph Ratzinger, logo após se tornar Bento XVI (SOUSA FILHO, 2009, p. 103).

Sobre a influência da liderança eclesiástica, Longaray e Ribeiro (2011, p. 118) remetem a Michel Foucault, o qual "menciona que o poder pastoral trouxe consigo uma série de mecanismos, técnicas, procedimentos que fazem referência à verdade ou à produção da verdade.” Acrescentam, ainda, no recorte que, o pastor cristão "ensina a verdade, ele ensina a escritura, a moral, ele ensina os mandamentos de Deus e os mandamentos da Igreja".

[...] por um lado, o pastor cristão, para exercer sua tarefa de pastor, deve saber, é claro, tudo o que fazem as suas ovelhas, tudo o que se passa na alma, no coração, no mais profundo dos segredos do indivíduo. Esse conhecimento da interioridade dos indivíduos é absolutamente exigido para o exercício do pastorado cristão. O que significa conhecer o interior dos indivíduos? Significa que o pastor disporá de meios de análise, de reflexão, de detecção do que se passa, mas também que o cristão será obrigado a dizer ao seu pastor tudo o que se passa no âmago de sua alma; particularmente, ele será obrigado a recorrer, do ponto de vista do seu pastor, a essa prática tão específica do cristianismo: a confissão exaustiva e permanente (LONGARAY; RIBEIRO, 2011, p. 118). 
Dessa forma, a religião cristã estabelece, por meio da educação, um modo de controlar os sujeitos através de sua sexualidade, algo que precisamos reprimir e desconfiar pelas possibilidades de sedução, tentação e de desejo $^{8}$, que leva ao pecado. O ato de governar os sujeitos é utilizado como forma de estabelecer o padrão normal de sexualidade, a heterossexualidade. Cada vez mais, os discursos religiosos vão incitando os sujeitos a agirem de determinada forma e assumirem determinadas posturas e falas restritas às representações particulares do grupo.

Nesse sentido, as igrejas são capazes de controlar o corpo, domesticar as práticas dos indivíduos, e isso através de discursos que proliferam cada vez mais, destacando a homossexualidade como uma atitude pecaminosa e contrária às leis de Deus. A orientação homossexual passa a ser vista como algo patológico, perverso, uma vez que não há a possibilidade de procriação e, portanto, correspondência com a constituição da família patriarcal, formada pelo casal heterossexual. "A legalização das uniões homossexuais acabaria, portanto, por ofuscar a percepção de alguns valores morais fundamentais e desvalorizar a instituição matrimonial" (CONGREGAÇÃO PARA A DOUTRINA DA FÉ, 2003). O matrimônio faz referência à família padrão, que tem por função o sexo para a perpetuação da vida, considerando a procriação uma das principais justificativas do ato sexual.

Por isso, a formação de professores deve oferecer uma pesquisa que parta de uma linguagem comum, proporcionando, por um lado, um movimento de encontro com a realidade dos educandos e, por outro, uma autonomia destes para a interpretação dos fatos de maneira crítica em relação às leituras bíblicas e de mundo apresentadas, no que tange à orientação homossexual. Dessa maneira, em termos de uma formação continuada dos educadores, o Plano Nacional de Educação em Direitos Humanos define que a Educação Básica precisa:

fomentar a inclusão, no currículo escolar, das temáticas relativas a gênero, identidade de gênero, raça e etnia, religião, orientação sexual, pessoas com deficiências, entre outros, bem como todas as formas de discriminação e violações de direitos, assegurando a formação continuada dos(as) trabalhadores(as) da educação para lidar criticamente com esses temas (BRASIL, 2007, p. 33).

Platão (427-347 a.C.) dividiu o corpo humano em três partes: cabeça (razão) - dirigida por filósofos que seriam os governantes, peito (vontade, defesa) - os sentinelas, e baixo-ventre (desejo ou prazer) - os trabalhadores. Imaginava que a temperança (homem íntegro) só era reconhecida quando as três partes agiam como uma totalidade. 
Espera-se uma formação que promova mudanças de paradigmas religiosos, a fim de combater qualquer tipo de preconceito, discriminação e violência, tendo no processo de ensino e de aprendizagem sua mola propulsora. Por isso, os desafios elaborados no final do século passado pelos Parâmetros Curriculares Nacionais (PCNs) continuam atuais, uma vez que,

o grande desafio da escola é reconhecer a diversidade como parte inseparável da identidade nacional e dar a conhecer a riqueza representada por essa diversidade etnocultural que compõe o patrimônio sociocultural brasileiro, investindo na superação de qualquer tipo de discriminação e valorizando a trajetória particular dos grupos que compõem a sociedade. Nesse sentido, a escola deve ser local de aprendizagem de que as regras do espaço público permitem a coexistência, em igualdade, dos diferentes (BRASIL, 1998a, p. 117).

A formação de educadores depara-se com a urgente necessidade de romper com dogmatismos preconceituosos, visando o reconhecimento do outro, a criação e o desenvolvimento de sujeitos respeitosos e que valorizem as diferenças. No âmbito do curso de formação de professores, como uma de suas finalidades, deve-se definir o combate à homofobia, com vistas a promover uma educação para a sexualidade pautada na afetividade, no respeito e na tolerância ante ao diferente. Cabe à escola entender e discutir as dimensões sociais que constituem a identidade dos sujeitos, compreendendo que o espaço escolar deve promover a problematização das questões vitais, mas sem reforçar preconceitos biológicos, como é feito por diversas vertentes religiosas. É muito importante que essa temática seja discutida na formação de educadores:

A pesquisa "Perfil dos Professores Brasileiros", realizada pela Unesco, entre abril e maio de 2002, em todas as unidades da federação brasileira, na qual foram entrevistados 5 mil professores da rede pública e privada, revelou, entre outras coisas, que, para $59,7 \%$ deles é inadmissível que uma pessoa tenha relações homossexuais e que $21,2 \%$ deles tampouco gostariam de ter vizinhos homossexuais [...] Outra pesquisa, realizada pelo mesmo organismo em 13 capitais brasileiras e no Distrito Federal, forneceu certa compreensão do alcance da homofobia no espaço escolar (nos níveis fundamental e médio). Constatou-se, por exemplo, que: o percentual de professores/as que declaram não saber como abordar os temas relativos à homossexualidade em sala de aula vai de 30,5\% em Belém a 47,9\% em Vitória; acreditam ser a homossexualidade uma doença cerca de $12 \%$ de professores/as em Belém, Recife e Salvador, entre 14 e $17 \%$ em Brasília, Maceió, Porto Alegre, Rio de Janeiro e Goiânia e mais de 20\% em Manaus e Fortaleza (JUNQUEIRA, 2009, p. 17).

No tocante ao silêncio e à violência, a questão mostra-se ainda mais grave, especialmente quando a escola, que deveria ser o espaço para a cons- 
trução de discussões democráticas, críticas e libertadoras, torna-se, na maioria das vezes, cenário de reações homofóbicas. Na formação de professores, portanto, o assunto requer uma postura de autorreflexão e compreensão no horizonte do mundo da vida contingente, uma vez que o papel do educador é o de promover a construção de uma ética fundada no respeito e na cidadania, necessidade básica para a convivência em grupo. Os docentes devem ser preparados para intervir em todas as situações em que haja manifestação de preconceitos homofóbicos, resistindo às alienações e preconceitos que deflagram a dignidade humana e os direitos dos cidadãos.

É necessário que o educador tenha acesso à formação específica para tratar de sexualidade com crianças e jovens na escola, possibilitando a construção de uma postura profissional e consciente no trato desse tema. Os professores necessitam entrar em contato com suas próprias dificuldades diante do tema, com questões teóricas, leituras e discussões referentes à sexualidade e suas diferentes abordagens; preparar-se para a intervenção prática junto aos alunos e ter acesso a um espaço grupal de produção de conhecimento a partir dessa prática, se possível contando com assessoria especializada (BRASIL, 1998b, p. 303).

Os cursos de formação propedêutica e permanente de professores tem ainda uma formação problemática sobre a questão da sexualidade, por isso, não basta desvalorizar os paradigmas de uma cultura conservadora, que ficou para trás, mas promover a superação de qualquer atitude de intolerância atual. Tendo em vista a proteção da dignidade humana, deve-se incentivar o respeito à diversidade de comportamentos relativos à sexualidade, reconhecendo as diferentes formas de vida e o seu direito à expressão. Com vistas à identificação e superação de tabus e preconceitos referentes à sexualidade, deve-se propor aos docentes que evitem comportamentos discriminatórios e intolerantes, sugerindo que se façam análises críticas dos estereótipos. Entender e trabalhar a educação sexual na formação de professores significa também prepará-los para apresentarem novas concepções, relacionadas principalmente à revisão de paradigmas religiosos. Trata-se de pensar sobre os conflitos e as contradições culturais, religiosas e educacionais em torno da sexualidade, buscando tecer algumas aproximações com o discurso religioso, além de discutir suas implicações para a constituição dos sujeitos, principalmente no tocante ao controle dos corpos e desejos. Os discursos produzidos interpelam os sujeitos e produzem efeitos na constituição de suas subjetividades, uma vez que instauram verdades provindas do imaginário social sobre determinadas formas de ser e estar em sociedade.

Entre as instâncias sociais, as instituições religiosas possuem os seus regimes de verdade, que se instauram através de múltiplos discursos reprodu- 
zidos na sociedade. Segundo Foucault (2006, p. 262), existem relações de saber e poder, ou seja, "o poder não opera em um único lugar, mas em lugares múltiplos: a família, a vida sexual, a maneira como se trata [sic] os loucos, a exclusão dos homossexuais, as relações entre os homens e as mulheres". Por isso, a homossexualidade, segundo algumas dessas instâncias religiosas, é uma identidade sexual anormal, assim como nos espaços educativos é visto como algo estranho, resultando em intimidações e deboche, pois não encontra justificação em vivências pedagógicas.

Nas narrativas, podemos perceber o quanto o discurso religioso permeia e instaura aquilo que é aceito ou não perante a sociedade, as leis e a educação. Nesse sentido, percebemos que o discurso religioso atravessa também a cultura dos educadores, fazendo-os reproduzir, no espaço escolar, ideologias, conhecimentos, interesses e poderes que controlam, vigiam e governam os corpos e as condutas dos sujeitos. Dessa forma, não se exerce um mecanismo de censura, porém, se estabelece uma relação incomunicável, de terreno intocado, velado e objetivado às diferentes expressões da sexualidade.

Tudo isso são questões sensíveis no tocante à educação, principalmente porque não há avanços em termos de leis e metodologias educacionais para abordar e debater o assunto no cotidiano escolar. O educador, quando utiliza os referenciais bíblicos para deslegitimar a homossexualidade, espera-se que oriente os educandos a partir de uma visão histórico-crítica, permitindo-lhes ver a realidade com outros olhos.

A escola, que deveria ser um lugar de inclusão e respeito da diversidade, muitas vezes perde a sua função e passa a desempenhar outras. Torna-se escola-polícia, escola-igreja, escola-tribunal, orientada por tecnologias sofisticadas de poder, centradas na disciplina dos corpos e na regulação dos prazeres. Distanciam-se, assim, de uma das funções da educação: tornar as pessoas preparadas para o convívio com as diferenças por meio da produção de sentimentos e atitudes de fraternidade, solidariedade e igualdade de direitos, valorizando o coletivo e garantindo o acesso à informação, sem o que é impossível às pessoas a construção de suas cidadanias (PERES, 2009, p. 249).

Neste momento, a educação faz-se necessária para que se elabore uma reflexão criteriosa acerca da transmissão de valores no que se refere à orientação homossexual. Dos espaços em que é possível realizar tal discussão, a escola, através da formação dos educadores, é aquele que possibilitará uma abordagem crítica, que parta de uma linguagem comum, à superação de paradigmas. Além disso, é necessário questionar a formação dos sujeitos que, vinculados a vertentes religiosas, fazem-se presentes no âmbito escolar, buscando aprofundar a discussão, a fim de promover o respeito e o combate à discriminação, a partir da conversação e da (re)interpretação. A prática 
educacional deve respeitar os princípios da lei com relação à laicidade do Estado, encorajando práticas não-proselitistas.

\section{Conclusão}

Conclui-se que se deve ter cuidado para não utilizar a Bíblia de maneira oportunista e condenatória, incutindo nos fiéis que buscam um Deus libertador uma verdade supostamente absoluta, porém, respaldando posições homofóbicas como condição pecaminosa e discriminatória, que causam uma espécie de sofrimento social. A palavra homossexualidade nunca foi citada na Bíblia, e as incitações contra as relações homossexuais são, hoje, consideradas ultrapassadas e fora da realidade. Portanto, os textos bíblicos devem ser compreendidos e lidos à luz dos períodos em que foram escritos, para se evitar condenações a priori. Afinal de contas, quando se afirma tratar-se de são palavras de Deus, a consciência popular facilmente aceita, sem questionamento aprofundado por meio de debates. O perigo maior encontra-se no respaldo que tais ideologias recebem de decisões políticas (aprovação de projetos de lei voltados à asseveração de preconceitos) e educativas, prejudicando o combate à homofobia em seus diversos aspectos provindos da sociabilidade racional.

Dessa forma, a influência das igrejas cristãs na formação moral dos educadores que se encontram nas escolas é notória, principalmente no que tange à homossexualidade. Alguns fatores são responsáveis, dentre eles: a falta de conhecimento do significado das palavras bíblicas e dos contextos históricos e culturais originalmente ligados a elas. O desafio da instituição de ensino é reconhecer a diversidade como parte da sociedade, investindo na superação de discriminações e alienações socioculturais. Esta pesquisa quer incentivar que, embora as escolas possuam em seu currículo conteúdos já elaborados, ocorra, em sala de aula, uma abertura dialógica, com vistas a discutir os dogmatismos e ideologias instituídas, apresentando a compaixão, a empatia e o reconhecimento do outro como valores morais fundamentais. A falta de acesso a informações científicas sobre a sexualidade humana e suas inter-relações, bem como a leitura simplista e insensível de textos religiosos de teor condenatório podem levar a atitudes preconceituosas e replicadoras de ações desumanizadas (frieza, recrudescimento ideológico e segregação), como a incapacidade de reconhecer e respeitar os direitos dos outros, gerando casos de homofobia nas instituições de ensino.

\section{Referências bibliográficas}

BÍBLIA de Jerusalém. Nova ed., revista e ampliada. São Paulo: Paulus, 2002. 
BORTOLINI, José. Como ler a Carta aos Romanos. São Paulo: Paulus, 1997.

BRASIL. Comitê Nacional de Educação em Direitos Humanos. Plano Nacional de Educação em Direitos Humanos. Brasília: Secretaria Especial dos Direitos Humanos, Ministério da Educação, Ministério da Justiça, UNESCO, 2007. Disponível em: <http://portal.mec.gov.br/ index.php?option $=$ com_docman\&view $=$ download\&alias $=2191$-plano-nacional-pdf\&category slug=dezembro-2009-pdf\&Itemid=30192> . Acesso em 08 de julho de 2017.

BRASIL. Secretaria de Educação Fundamental. Parâmetros Curriculares Nacionais: terceiro e quarto ciclos do ensino fundamental. Apresentação dos temas transversais. Brasília: MEC/SEF, 1998a. v. 10.2: Temas Transversais - Pluralidade Cultural. Disponível em: <http://portal.mec. gov.br/seb/arquivos/pdf/pluralidade.pdf>. Acesso em 08 de julho de 2017.

BRASIL. Secretaria de Educação Fundamental. Parâmetros Curriculares Nacionais: terceiro e quarto ciclos do ensino fundamental. Apresentação dos temas transversais. Brasília: MEC/SEF, 1998b. v. 10.5: Temas Transversais - Orientação Sexual. Disponível em: <http://portal.mec. gov.br/seb/arquivos/pdf/orientacao.pdf>. Acesso em 08 de julho de 2017.

CONGREGAÇÃO PARA A DOUTRINA DA FÉ. Considerações sobre os projetos de reconhecimento legal das uniões entre pessoas homossexuais. Roma, 2003. Disponível em: <http://www.vatican.va/roman_curia/congregations/cfaith/documents/rc_con_cfaith_doc_20030731_homosexual-unions_po.html $>$. Acesso em 08 de julho de 2017.

DINIS, Nilson Fernandes. Homofobia e educação: quando a omissão também é signo de violência. Educar em Revista, Curitiba, n. 39, p. 39-50, 2011. Disponível em: <http://www. scielo.br/pdf/er/n39/n39a04.pdf>. Acesso em 08 de julho 2017.

DUBE, Yvette. Homossexualidade e a Bíblia: Apostila II. Tradução de José Luiz V. Silva. Rio de Janeiro: Igreja da Comunidade Metropolitana do Rio de Janeiro, 2007. 49p. Disponível em: <http://www.icmrio.com/wp-content/uploads/2016/02/ahomossexualidadeeabiblia. pdf $>$. Acesso em 06 de julho de 2017.

FOUCAULT, Michel. Estratégia, poder-saber. 2. ed. Rio de Janeiro: Forense Universitária, 2006. (Ditos \& Escritos, 4).

HELMINIAK, Daniel. O que a Bíblia realmente diz sobre a homossexualidade. São Paulo: Edições GLS, 1998.

HABERMAS, Jürgen. O Discurso Filosófico da Modernidade. Lisboa: Dom Quixote, 1990.

JUNQUEIRA, Rogério Diniz. Homofobia nas Escolas: um problema de todos. In: JUNQUEIRA, Rogério Diniz (Org.). Diversidade Sexual na Educação: problematizações sobre a homofobia nas escolas. Brasília: Ministério da Educação, Secretaria de Educação Continuada, Alfabetização e Diversidade, UNESCO, 2009. p. 13-51. Disponível em: <http://unesdoc.unesco.org/images/0018/001871/187191por.pdf>. Acesso em 08 de julho de 2017.

LONGARAY, Deise Azevedo; RIBEIRO, Paula Regina Costa. “... A minha religião não aceita homossexuais": analisando narrativas de adolescentes sobre religião e homossexualidade. In: SILVA, Fabiane Ferreira da; MELLO, Elena Maria Billing (Orgs.). Corpos, gêneros, sexualidades e relações étnico-raciais na educação. Uruguaiana: UNIPAMPA, 2011. p. 115-131. Disponível em: <https://pibidlcn2009.files.wordpress.com/2013/03/ebook-seminc3a1rio-2011.pdf>. Acesso em 07 de julho de 2017.

MONTALVÃO, Sérgio Aguiar. A homossexualidade na Bíblia Hebraica: um estudo sobre a prostituição sagrada no antigo Oriente Médio. 2009. 176 p. Dissertação de Mestrado em 
Letras. Programa de Pós-Graduação em Língua Hebraica, Literatura e Cultura Judaica do Departamento de Letras Orientais da Faculdade de Filosofia, Letras e Ciências Humanas da Universidade de São Paulo, São Paulo, 2009. Disponível em: <http://www.teses.usp.br/ teses/disponiveis/8/8152/tde-16112009-113815/publico/SERGIO_AGUIAR_MONTALVAO.pdf>. Acesso em 07 de julho de 2017.

PERES, Wiliam Siqueira. Cenas de exclusões anunciadas: travestis, transexuais, transgêneros e a escola brasileira. In: JUNQUEIRA, Rogério Diniz (Org.). Diversidade Sexual na Educação: problematizações sobre a homofobia nas escolas. Brasília: Ministério da Educação, Secretaria de Educação Continuada, Alfabetização e Diversidade, UNESCO, 2009. p. 235-263. Disponível em: <http://unesdoc.unesco.org/images/0018/001871/187191por.pdf>. Acesso em 07 de julho de 2017.

SALZMAN, Todd A. A pessoa sexual: por uma antropologia católica renovada. Tradução Luzia Araújo. São Leopoldo, RS: Ed. UNISINOS, 2012.

SEFFNER, Fernando. Equívocos e armadilhas na articulação entre diversidade sexual e políticas de inclusão escolar. In: JUNQUEIRA, Rogério Diniz (Org.). Diversidade Sexual na Educação: problematizações sobre a homofobia nas escolas. Brasília: Ministério da Educação, Secretaria de Educação Continuada, Alfabetização e Diversidade, UNESCO, 2009. p. 125-139. Disponível em: <http://unesdoc.unesco.org/images/0018/001871/187191 por. pdf>. Acesso em: 07 de julho de 2017.

SOUSA FILHO, Alípio de. Teorias sobre a gênese da homossexualidade: ideologia, preconceito e fraude. In: JUNQUEIRA, Rogério Diniz (Org.). Diversidade Sexual na Educação: problematizações sobre a homofobia nas escolas. Brasília: Ministério da Educação, Secretaria de Educação Continuada, Alfabetização e Diversidade, UNESCO, 2009. p. 95-123. Disponível em: <http://unesdoc.unesco.org/images/0018/001871/187191por.pdf>. Acesso em 07 de julho de 2017.

TORRES, Milton. A evidência linguística e extralinguística para a tradução de Arsenokoitai. Revista Hermenêutica, Cachoeira, BA, vol. 12, n. 2, p. 25-49, 2012. Disponível em: <https:// www.andrews.edu/library/car/cardigital/Periodicals/Hermeneutica/2012/2012_02.pdf>. Acesso em 07 de julho de 2017.

WEGNER, Uwe. Exegese do Novo Testamento. São Leopoldo: Sinodal, 1998.

Submetido em: 8-5-2017

Aceito em: 21-6-2017 